\title{
European networks for nursing: the exchange of valuable knowledge in times of covid - discussion paper
}

\author{
Joep Grosemans ${ }^{1}$, Lenka Šáteková ${ }^{2}$
}

${ }^{1}$ Department PXL-Healthcare, PXL University College, President at ENNE Network, Hasselt, Belgium

${ }^{2}$ Department of Nursing, Faculty of Health Sciences, Palacký University in Olomouc, Czech Republic

\begin{abstract}
There are several networks represent the nursing profession in an international context. The European Network of Nursing in higher Education is one of them. It includes 14 partners from European countries. The main goal of ENNE is to support quality improving innovations in nursing education and broaden students' horizons to the European workfield. ENNE offers a lot of possibilities: different strategies to serve nursing students as well as teachers, project leaders and researchers, organization of coordinators meeting and student conference, promotion and support to students and teacher exchange, ... The COVID-19 pandemic has offered new challenges for any international network, but for ENNE in particular.
\end{abstract}

\section{KEY WORDS}

The European Network of Nursing in higher Education, COVID-19, nursing education, international network, nursing

\section{INTRODUCTIONS}

Probably none of us expected the course of the beginning and continuation of the year 2020. All started with one news. On 31 December 2019, the Wuhan City Health Committee (1) reported a set of 27 cases of pneumonia of unknown etiology, with a preliminary source linking the now closed Wuhan Huanan seafood market. It was founded as new coronavirus (COVID-19). By 20 January 2020, there had been 295 laboratory-confirmed cases, of which 291 were from Wuhan, China (2). Since then, the number of infected people has increased worldwide. According to the World Health Organization (3), as of 31 March 2020, 697,244 cases with 33,257 deaths (4.77\% mortality) were confirmed. The World Health Organization (4) has declared COVID-19 a pandemic. The top ten countries reported are China, Italy, the United States, Spain, Germany, Iran, France, South Korea, Switzerland and the United Kingdom (3).

The COVID-19 pandemic has affected all aspects of our lives. One of the main areas that has undergone a major transformation is higher education. This sector faced the need to respond to the evolving situation (5). The teaching of which has been digitized almost overnight around the world. Campuses were ordered to be evacuated and classrooms, laboratories, dormitories and cafeterias abandoned. In an effort to pre- vent the further spread of the virus, schools canceled promotions (6). Faculties have rushed to translate the curriculum into an online technology-aware environment. Enlargement to South Korea, then to Iran and Italy has led to the higher education sector in the affected countries shifting to focusing on its own operations (7). Many researchers have questioned whether higher education is ready for the coming digital era of learning (8).

The teaching is not the only affected component of higher education. Another component of this sector is international mobility. According to the latest UNESCO 2019 statistics (9), there were around 5.3 million international students worldwide in 2017, and these numbers are constantly increasing. This overall mobility of trends is expected to slow down in the coming years, if not abruptly. The decline in the number of international students will have serious consequences for higher education institutions, especially for those for whom tuition fees are the main source of income. Several options have been described for how universities have saved money: substantial layoffs of adjunct faculty members and temporary contracts (6). The COVID-19 also affected the international networks. Due to restrictive interventions, it was not possible to travel by plane. Face-to-face meetings have been cancelled. We, as one of the members of one inter- 
national network, would like to continue to focus on the impact of COVID-19 on this type of international cooperation.

\section{The European Network of Nursing in higher Education}

Several networks represent the nursing profession in an international context. Some are very large and focus on the nursing professional in general. Others aim at cooperation for more specific topics. The European Network of Nursing in higher Education (ENNE) is a network with 14 partners from all corners of Europe: Austria, Belgium, Croatia, Czech Republic, England, Estonia, Finland, Germany, Hungary, Netherlands, Scotland, Spain, Sweden, Switzerland. It was founded in 1998. Palacký University Olomouc was one of the early members and joined ENNE in early 2000s.

The main goal of ENNE is to support quality improving innovations in nursing education and broaden students' horizons to the European work field according to the EU/2013/55 directive. Starting from the comparison of regional similarities and differences, ENNE looks for the competence profile of "the ultimate European nurse", and ways to integrate this in nursing education. Next to regional differences, nursing education in itself is subject to continuous change. Innovations such as the integration of knowledge and skills in competencies, the growing importance of Evidence Based Practice... have emerged in all European countries in similar time frames. Rather than to struggle with these changes on an individual university level, members can turn to ENNE for sharing expertise and taking up joint projects.

ENNE has developed different strategies to serve nursing students as well as teachers, project leaders and researchers. Next to the annual coordinators meeting and student conference, ENNE offers a platform in which universities can safely compare their pedagogical approach and exchange best practices regarding innovative learning strategies in peer groups. So far, these benchmarking activities have addressed learning strategies such as Problem Based Learning, e-learning, blended learning, high fidelity simulation and modern techniques for placement mentorship. ENNE also promotes and supports individual student and teacher exchange between its members to enhance new experiences. After all, being able to adapt and function in a complete new and strange setting, is a victory for one's development, that will affect your practice and career for several years.

The COVID-19 pandemic has offered new challenges for any international network, but for ENNE in particular. On one hand, the feasibility of international travelling can easily be questioned, certainly for conferences. We all have become acquainted with digital meeting media such as Zoom and Microsoft Teams ${ }^{\circ}$ in the past months. But these media lack the cultural experiences and demand much less adaptation to a strange and new context, compared to residing in foreign country. We will have to focus on new ways to teach intercultural and international competences, much needed by nurses.

At the same time, nursing students everywhere in Europe are experiencing serious issues during internships. During the spring semester, many of them were confronted with a healthcare service in crisis, have been relocated to another ward or were unable to graduate because their placement was suspended. Some experienced a lack of personal preventive equipment, were afraid to get contaminated or contaminated family members back at home. But they also showed great resilience in dealing with these uncomfortable situations. And with proper coaching and support, some of them were able to realize more learning goals in this strange situation, than they ever could have in a traditional placement situation. One could argue that some of the challenges caused by COVID-19 are closely related to the ones on an international exchange. But we all agree that the latter is the safer way to achieve these "adaptive competences".

Again, the question rises what we have learned from this experience. How will we act if next winter COVID-19 numbers are rising once again? This is where networks such as ENNE play an important role. Rather than inventing the warm water all at the same time, we should look for best practices amongst our peers, implement them and improve the quality and efficiency of our educations.

So while mobility is challenged more than ever before, the need for sharing knowledge and international comparison is immanent. From the ashes rises the Fenix...

\section{CONCLUSION}

The COVID-19 pandemic has offered new challenges for all of the world, for any international network. New views, attitudes and thinking are needed. The ENNE use for its work digital meeting media such as Zoom and Microsoft Teams ${ }^{\oplus}$. But there is a need to focus on new ways how to teach intercultural and international competences by nurses. The question rises what we have learned from this experience. We think that the need for sharing knowledge and international comparison is immanent. 


\section{REFERENCE}

1. Wuhan City Health Committee [Internet]. Wuhan Municipal Health and Health Commission's briefing on the current pneumonia epidemic situation in our city 2019. 2019 [cited 2020 September 12]. Available from: http://wjw.wuhan.gov.cn/front/ web/showDetail/2019123108989

2. European Centre for Disease Prevention and Control [Internet]. Risk assessment: Outbreak of acute respiratory syndrome associated with a novel coronavirus, Wuhan, China; first update. 2020 [cited 2020 September 10]. Available from: https:// www.ecdc.europa.eu/en/publications-data/ risk-assessment-outbreak-acute-respiratory-syndrome-associated-novel-coronavirus

3. World Health Organization. Coronavirus disease (COVID-2019) situation reports [Internet]. Situation report - 64. 2020 [cited 2020 March 29]. Available from: https://www.who.int/emergencies/ diseases/novel-coronavirus-2019/situation-reports

4. World Health Organization [Internet]. WHO Director-General's opening remarks at the media briefing on COVID-19. 2020 [cited 2020 March 11]. Available from: https://www.who.int/ $\mathrm{dg} /$ speeches/detail/who-director-general-s-opening-remarks-at-the-media-briefing-on-COVID19---11-march-2020

5. Crawford J, Butler-Henderson K, Rudolph J, Malkawi B, Glowatz M, Burton R, Magni PA, Lam S. COVID-19: 20 countries' higher education intra-period digital pedagogy responses. Journal of Applied Learning \& Teaching. 2020;3(1):9-28.

6. Bilecen, B. Commentary: COVID-19 Pandemic and Higher Education: International Mobility and Students' Social Protection. International Migration. 2020;58(4):263-266.

7. UNESCO [Internet]. COVID-19 Educational disruption and response. 2020 [cited 2020 September 01]. Available from: https://en.unesco. org/themes/education-emergencies/coronavirusschool-closures

8. Houlden S, Veletsianos, G [Internet]. Coronavirus pushes universities to switch to online classes but are they ready? 2020 [cited 2020 September 09]. Available from: https://theconversation. $\mathrm{com} /$ coronavirus-pushes-universities-to-switchto-online-classes-but-are-they-ready- 132728

9. UNESCO [Internet]. Outbound Internationally Mobile Students by Host Region. 2019 [cited 2020 June 14]. Available from: http://data.uis.unesco. org/Index.aspx?queryid $=172$
KORESPONDUJÍCÍ AUTOR

Mgr. Lenka Šáteková, Ph.D.

Ústav ošetřovatelství

Fakulta zdravotnických věd

Univerzita Palackého v Olomouci

Hněvotínská 976/3

77515 Olomouc

lenka.satekova@upol.cz

+420585632821 